This is an author produced version of a paper published in Applied Animal Behaviour Science.

This paper has been peer-reviewed but may not include the final publisher proof-corrections or pagination.

Citation for the published paper:

L.J. Keeling, K.E. Bøe, J.W. Christensen, S. Hyyppä, H. Jansson, G.H.M Jørgensen, J.Ladewig, M. Mejdell, S. Särkijärvi, E. Søndergaard, E.

Hartmann. (2016) Injury incidence, reactivity and ease of handling of horses kept in groups: A matched case control study in four Nordic countries.

Applied Animal Behaviour Science. Volume: 185, pp 59-65.

http://dx.doi.org/10.1016/j.applanim.2016.10.006.

Access to the published version may require journal subscription.

Published with permission from: Elsevier.

Standard set statement from the publisher:

(C) Elsevier, 2016. This manuscript version is made available under the CC-BY-NC-ND

4.0 license http://creativecommons.org/licenses/by-nc-nd/4.0/

Epsilon Open Archive http://epsilon.slu.se 


\title{
Injury incidence, reactivity and ease of handling of horses kept in groups: A matched case control study in four Nordic countries
}

\author{
Authors: L.J. Keeling, K.E. Bøe, J.W. Christensen, S. Hyyppä, H. Jansson, G.H.M Jørgensen, J. \\ Ladewig, M. Mejdell, S. Särkijärvi, E. Søndergaard, E. Hartmann
}

Published 2016 in: Applied Animal Behaviour Science 185, p. 59 - 65

https://doi.org/10.1016/j.applanim.2016.10.006

Highlights

- Severity of injuries in horses used to being kept in groups is overestimated.

- Most injuries recorded after mixing horses and four weeks later were minor.

- Group composition has little effect on injury, reactivity, and handling than breed.

\begin{abstract}
There is increasing interest in keeping horses in groups, but progress is hampered by a lack of knowledge about which horses can and should be kept together. Therefore, our objective was to investigate the effect of group composition on the occurrence of injuries among horses, the ease of removing horses from groups and horses' reactivity to a fearful stimulus. Using a matched case control design, 61 groups of horses were studied in Denmark, Norway, Finland and Sweden. They were allocated into groups of similar or different age and sex or where membership changed regularly or remained stable. Injuries were recorded before mixing the horses into treatment groups, the day after mixing and four weeks later. Reactivity of horses to a moving novel object and the behaviour of a horse being removed from its group and the reactions of other group members towards this horse and the handler were evaluated. It was hypothesized that a more socially variable group composition has beneficial effects on behaviour, ease of handling and reducing reactivity whereas frequent changes in group composition has negative consequences, resulting in more injuries. We found that differences in treatment effects were mainly related to breed, rather than group composition. Icelandic horses reacted less to the movement of the novel object $(\mathrm{P}=0.007)$ and approached it more afterwards $(\mathrm{P}=0.04)$. They also had fewer new injuries than warmbloods following mixing $(\mathrm{P}<0.001)$ and fewer than all other groups 4 weeks later $(\mathrm{P}<0.01)$. Most new injuries after mixing were minor and recorded on the horse's head, chest, hind legs and rump. In conclusion, variations in sex and age composition of the group had little effect on injury level, reactivity and ease of handling compared to the general effect of breed. Concerns about the risk of severe injuries associated with keeping horses in groups are probably overestimated. Thus, we propose that horses can be successfully kept in groups of different sex and age composition.
\end{abstract}

\section{Introduction}

Despite the fact that group housing is common in most farm animals, many horses are still kept singly during a large part of the day, although there is much evidence showing the benefits of keeping horses in groups (Hartmann et al., 2012a). A problem seems to be a lack of knowledge about which horses 
can and should be kept together and a concern about the risk of severe injuries associated with keeping horses in groups (Hartmann et al., 2015). Some stallions and horses used for competition purposes are never kept with conspecifics and other horses are only part time members of a group, being kept alone at night and in groups during the daytime (Knubben et al., 2008b; Wylie et al., 2013; Hartmann et al., 2015). The main reason for not keeping horses in groups seems to be owners' concerns related to the risk of injuries in horses (Hartmann et al., 2015). There are studies supporting that injuries can be severe, for example, as a result from being kicked by another horse (Fürst et al., 2006; Knubben et al., 2008a), but how much this is due to the lack of space and competition over resources and how much to the social environment, i.e. the group composition, is not clear (Flauger and Krueger, 2013). Another concern is that injuries are more likely to occur to a person when a horse is being removed from a group (Hartmann et al., 2012b). However, there is to our knowledge no large scale study that systematically addresses whether these concerns are justified, even if it is well documented that features of the social and physical environment of an animal as well as details of the management affect behaviour (Fureix et al., 2012). One reason for the lack of research in this area may be the difficulty of establishing large numbers of horse groups where these aspects are systematically varied.

This study was a collaborative effort among researchers in Sweden, Norway, Denmark and Finland using different breeds of horses to investigate keeping horses in groups under a diverse range of social and physical conditions. The treatments that were used in this study were the age and sex composition of the group and the stability of the group (i.e. whether new horses were added regularly and others removed). These aspects are most variable in practice and may be expected to affect the behaviour of horses (Bourjade et al., 2008). The hypothesis was that more varied groups (mixed age or sex) would be easier to manage, in terms of separating a horse from its group, and would result in horses reacting less to novel objects in their environment. The latter was predicted based on results from Christensen et al. (2008) showing that a calm companion horse reduces fear reactions in naïve test horses. As older horses tend to be calmer (Bourjade et al., 2008), a group with a mixture of older and younger horses could be expected to be less reactive. Further, we predicted fewer injuries with a stable composition of group members and in groups with horses of different ages and sexes, related to the presumed less time needed to establish and maintain dominance relationships. Parts of these data have been presented previously (Christensen et al., 2011; Jørgensen et al., 2009), but this is the first time all data has been combined in a single analysis.

\section{Methods}

The research conducted in this study adhered with local ethical guidelines in each participating country.

\subsection{Treatment groups}

Using a matched case control design balanced within country, farm and breed of horse, new groups of horses were formed to investigate each of the different grouping strategies. In total, 61 groups (233 horses) were involved in the study which was carried out between September 2007 and November 2008 (Table 1). There were 24 groups used to investigate the treatment comparison 'similar age' (young horses between 1 and 3 years old kept together) versus 'mixed age' (horses from 1 to 19 years old kept together), 22 groups to investigate the treatment comparison 'mixed sex' (mares and geldings kept together) versus 'single sex' (mares and geldings/colts kept separately), and 15 groups to investigate the treatment comparing 'stable' (group membership unchanged) versus 'dynamic' (one 
horse was removed from the group once per week during 6 weeks and replaced with a new horse from another dynamic group).

Table 1. Overview of number of horse groups (and number of horses) of each breed kept according to treatment in each country.

\begin{tabular}{|c|c|c|c|c|c|c|}
\hline \multirow{2}{*}{$\begin{array}{l}\text { Treatment } \\
\text { Sex }\end{array}$} & \multirow[t]{2}{*}{ Country } & \multirow[t]{2}{*}{ Horse breed } & \multicolumn{3}{|c|}{ Number of Groups (Horses) } & \multirow[t]{2}{*}{ Total } \\
\hline & & & mixed & female & male & \\
\hline & Norway & Warmblood & $1(4)$ & $1(3)$ & $1(3)$ & $3(10)$ \\
\hline & & Icelandic & $3(12)$ & $3(11)$ & $3(11)$ & $9(34)$ \\
\hline & Denmark & Icelandic & $1(4)$ & $1(3)$ & $1(3)$ & $3(10)$ \\
\hline & & Other $^{\mathrm{a}}$ & $1(3)$ & $1(4)$ & $1(3)$ & $3(10)$ \\
\hline & Finland & Other ${ }^{\mathrm{b}}$ & & $2(11)$ & $2(13)$ & $4(24)$ \\
\hline & Total & & $6(23)$ & $8(32)$ & $8(33)$ & $22(88)$ \\
\hline \multirow[t]{7}{*}{ Age } & & & mixed & similar & & \\
\hline & Norway & Icelandic & $2(10)$ & $2(8)$ & & $4(18)$ \\
\hline & Denmark & Icelandic & $5(24)$ & $5(21)$ & & $10(45)$ \\
\hline & & Warmblood & $2(8)$ & $2(6)$ & & $4(14)$ \\
\hline & Finland & Other $^{\mathrm{b}}$ & $2(8)$ & $2(7)$ & & $4(15)$ \\
\hline & Sweden & Warmblood & $1(4)$ & $1(4)$ & & $2(8)$ \\
\hline & Total & & $12(54)$ & $12(46)$ & & $24(100)$ \\
\hline \multirow[t]{2}{*}{ Stability } & & & stable & dynamic & & \\
\hline & Denmark & Warmblood & $7(21)$ & $8(24)$ & & $15(45)$ \\
\hline
\end{tabular}

${ }^{\mathrm{a} G r o u p s ~ o f ~ I c e l a n d i c ~ h o r s e, ~ S h e t l a n d ~ p o n y ~ a n d ~ F j o r d ~ h o r s e . ~}{ }^{\mathrm{b}}$ Groups of Finn-horse, Halfblood, Standardbred.

The majority of horses were privately owned and mostly used for leisure purposes or they were young, untrained horses. All horses were accustomed to being kept in groups. For the purpose of our experimental design, horses were mixed into new groups (different group members than prior to each study) where they remained for at least 4 weeks. They were kept in groups on pasture for the entire $24 \mathrm{~h}$ period and some had either free or restricted access to additional roughage.

Three different types of data were collected for each horse. These were the number of injuries (including lameness) before and after grouping, a reactivity score for the reaction to a novel object and a score for the ease of removing a horse from the group after mixing horses into treatment groups. The reactivity and the separation test were not carried out on the stable/dynamic treatment groups as those horses were also part of another study. 


\subsection{Injury scoring}

Each horse was inspected three times; at day 0, before the horses were placed into the treatment groups (baseline recording to know which injuries were present before mixing), the day after mixing and again at least 4 weeks after mixing. Injuries were recorded on the same spreadsheet for each horse during all three occasions which allowed us to only record new injuries at the second and third inspection after grouping. On the protocol, the position of the injury on the horse's body (see Fig. 1) and the severity of any injury or lameness were recorded. A complete description for each of the lesion scores and how the injury scoring system was validated is presented in Mejdell et al. (2010). Skin lesions obviously related to itching, ringworm and forms of pastern dermatitis were not recorded. Lameness, if observed, was scored on a 5-point scale ( 1 = slightly lame, up to 5 = very lame; adapted from American Association of Equine Practitioners (AAEP), 2015). All inspections were carried out by observers well trained in the scoring system and experienced with horses. During inspections, horses were haltered to allow a thorough examination.

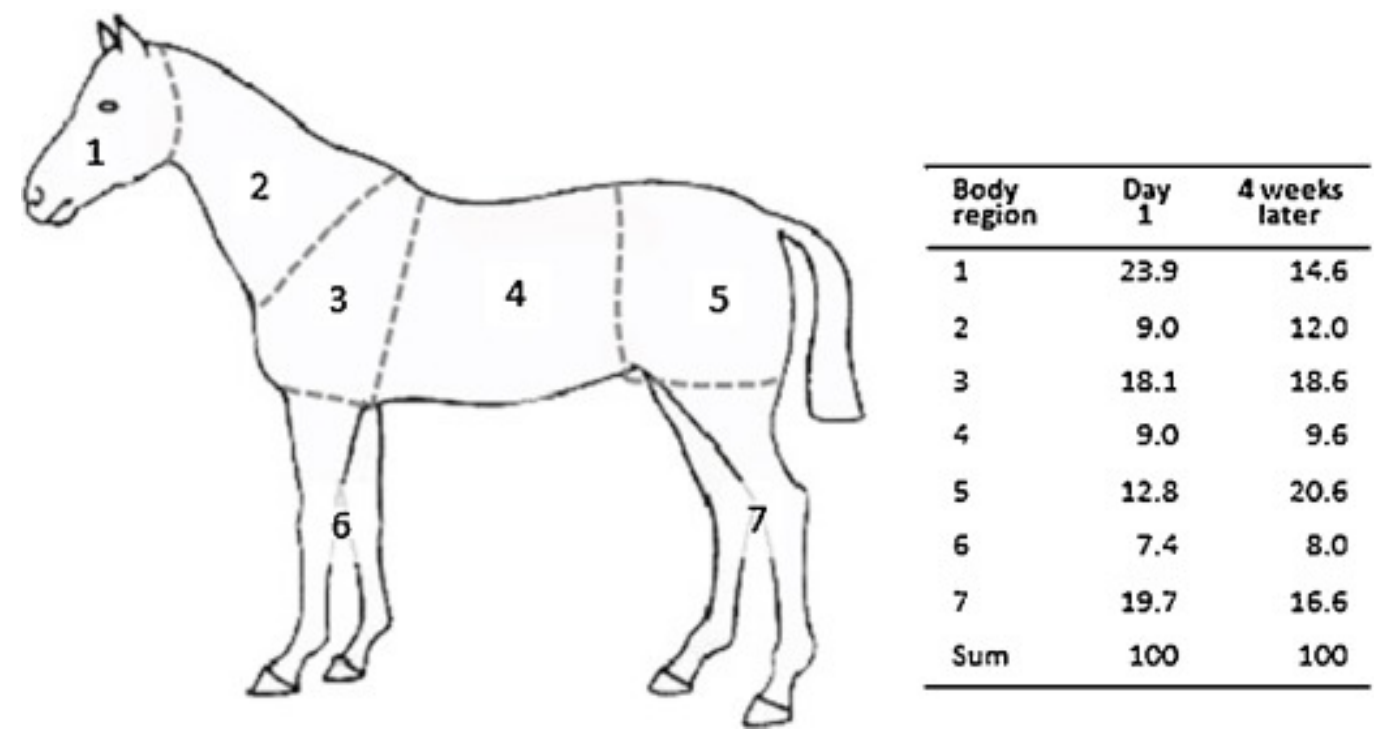

Fig. 1. Distribution of new injuries (in percent) on the horses' body regions recorded on day 1 and 4 weeks after grouping. Injury scores were: $1=$ Lesion involving hair loss only, $2=$ Lesion involving a moderately swollen area and/or a superficial wound, but the skin is not cut through, $3=$ Lesion involving a (minor) cut through the skin, $4=$ Wound through the skin of a size that normally should be sutured by a vet, 5 = Extensive and severe injury that may lead to long lasting loss of function. A more complete description of the wound scores is provided in Mejdell et al. (2010).

\subsection{Group reactivity test}

Before the start of the reactivity test, small portions of hay and some concentrate feed (same number of portions as horses in the group) were placed $1.5 \mathrm{~m}$ apart in a row on the ground. The test person then entered the paddock with the novel object (4 conventional $0.5 \mathrm{l}$ plastic bottles filled with stones bound to a $15 \mathrm{~m}$ rope) hidden behind her back. The person placed the object $10 \mathrm{~m}$ away from the fence, approximately $5 \mathrm{~m}$ in front of the feeding horses, and walked the same way back to the fence, keeping hold of the other end of the rope. When the person was out of the paddock, and 2 min had passed since the object had been placed on the ground, the rope was forcefully pulled towards the fence so that the bottles moved and made a sound.

The reactions of each horse in the group were recorded during the 2 min when the bottles had been placed in the paddock ('before'), when the bottles were suddenly moved ('during') and during the 
2 min subsequently ('after'). Four different categories of response were recorded; 'no reaction' (horse remains stationary and continues feeding, may raise head from feed while chewing continues) and 'flight' (horse jumps or runs away from feed with elevated head, may snort forcefully) were recorded both before and during the bottles were moved, whereas the categories 'investigate' (horse approaches object, lowers its head to sniff or may move the object with its nose or front legs), and 'resume feeding' (horse returns to the feed portions) were only recorded after the bottles were moved. From this information, the proportion of horses reacting in each group was determined. No other treatment groups were in visual range of the group being tested. Thus, no horses had observed the novel object prior to being tested themselves.

\subsection{Separating a horse from the group}

Each horse in the group was approached individually in a predetermined, random order by an unfamiliar person. The approach, how the halter was put on the horse and how the horse was led out of the field and through the gate was carried out in a standardized way. For each stage of the removal process, the ease with which it was done to reflect the risk of injury to horse or human was scored on a scale from 1 to 3 (see Table 2). The horse was led back into the field and returned to the group after being held for approximately 2 min outside the field next to the gate. Immediately after the horse had been released, another horse was approached and removed from the group. In total, 195 horses were separated from a total of 42 groups.

Table 2. Ethogram of the behaviour of the target horses and the other horses in the group when removing a horse from its group.

\section{Observation}

\section{Score Description}

Behaviour of target horse

While person approaches horse and puts halter on

While person leads horse to the gate and passes gate
Behaviour of other horses
Horse approaches friendly or is approached, haltered at 1 st attempt

\section{Horse is haltered at 2nd or 3rd attempt}

Horse cannot be haltered

Horse follows person easily without resistance to the gate, may stop once but walks through gate

Horse resists following and walking through the gate once or twice, but then passes gate

Horse escapes or cannot be led through the gate

Horse(s) don't approach or move out of way of person

While person approaches target horse, puts halter on and leads it to the gate

Horse(s) approach, may follow but are easily hushed away not easily hushed away 


\subsection{Data analysis}

The non-parametric Wilcoxon signed rank test was used to compare the number of new injuries recorded the day after mixing and 4 weeks later between matched treatment groups, evaluating the effect of group composition (same versus mixed sex and age) and breed. The Wilcoxon signed rank test was also applied to compare the proportion of horses reacting in the different ways towards the novel object and to compare behavioural responses when a single horse was being removed between the groups of horses matched for treatments (similar and mixed age, same and mixed sex). MannWhitney $\mathrm{U}$ tests were used for comparing reactivity and the average number of injuries between the different breeds. We were not able to address potential interactions between treatment factors, such as age or sex, in this analysis, but the matched case control design accounts for variations between other aspects of management, paddock design, weather conditions etc. between farms and countries that we know can affect behaviour.

Results are presented as medians and first and third quartiles (Q1, Q3) with the exception of the number of new injuries per horse which is presented as mean and standard error. The significance level was set at $\mathrm{P}<0.05$. Data were analysed in Minitab Statistical Software (version 16.2.4, Minitab Ltd., 2013).

\section{Results}

\subsection{Injury}

Injury occurrence was recorded in 233 horses. A total of 1088 injuries were scored in this study of which 597 injuries were registered before grouping on day 0,188 new injuries after grouping day 1 , and 303 new injuries after 4 weeks. The majority of injuries were minor, recorded on day 1 (category 1: $151,80.3 \%$; category 2: 33, 17.6\%) and 4 weeks later (category 1: 232, 77.3\%; category 2: 61 , 20.3\%). A total of 3 (day 1 ) and 6 (4 weeks later) injuries were of category 3 . The maximum score given was 4 and it was registered only twice, in 1-2 year old warmblood horses (one horse day 1, one horse 4 weeks later).

There was no difference between mixed age and similar age groups, mixed sex and same sex groups or the stable and dynamic groups in the mean number of new injuries recorded day 1 or 4 weeks after mixing ( $\mathrm{P}>0.05$, Table 3). Icelandic horses had significantly fewer injuries than warmbloods on day 1 ( $\mathrm{W}=17189, \mathrm{P}<0.001$, Table 3). After 4 weeks, Icelandic horses had fewer injuries compared to warmbloods $(\mathrm{W}=8046, \mathrm{P}<0.001)$ and groups of mixed breeds $(\mathrm{W}=4452, \mathrm{P}=0.003$, Table 3$)$.

Table 3. Number of horses in each treatment and mean ( $+S E)$ number of new injuries per horse recorded day 1 after grouping and additional new injuries after 4 weeks.

\begin{tabular}{|c|c|c|c|c|c|}
\hline Treatment & $\begin{array}{l}\text { Total } \\
\text { number } \\
\text { horses }\end{array}$ & $\begin{array}{l}\text { Number of } \\
\text { horses with new } \\
\text { injuries } \\
\text { on day } 1\end{array}$ & $\begin{array}{l}\text { Number of horses } \\
\text { with new injuries } 4 \\
\text { weeks later }\end{array}$ & $\begin{array}{l}\text { New injuries per } \\
\text { horse on day } 1\end{array}$ & $\begin{array}{l}\text { New injuries per } \\
\text { horse } 4 \text { weeks } \\
\text { later }\end{array}$ \\
\hline
\end{tabular}

\begin{tabular}{llllll}
\hline Age & & & & & \\
Mixed & 68 & 21 & 25 & $0.4 \pm 0.1$ & $0.6 \pm 0.2$ \\
Similar & 59 & 15 & 31 & $0.4 \pm 0.2$ & $0.9 \pm 0.2$ \\
\hline
\end{tabular}




\begin{tabular}{|c|c|c|c|c|c|}
\hline Treatment & $\begin{array}{l}\text { Total } \\
\text { number } \\
\text { horses }\end{array}$ & $\begin{array}{l}\text { Number of } \\
\text { horses with new } \\
\text { injuries } \\
\text { on dav } 1\end{array}$ & $\begin{array}{l}\text { Number of horses } \\
\text { with new injuries } 4 \\
\text { weeks later }\end{array}$ & $\begin{array}{l}\text { New injuries per } \\
\text { horse on day } 1\end{array}$ & $\begin{array}{l}\text { New injuries per } \\
\text { horse } 4 \text { weeks } \\
\text { later }\end{array}$ \\
\hline
\end{tabular}

\begin{tabular}{lccccc}
\hline Sex & & & & \\
Female & 29 & 14 & 8 & $4.2 \pm 1.3$ & $0.7 \pm 0.5$ \\
Male & 26 & 11 & 17 & $3.6 \pm 3.1$ & $1.5 \pm 0.4$ \\
Mixed & 17 & 1 & 7 & $5.9 \pm 5.2$ & $1.8 \pm 1.0$ \\
Stability & & & & & \\
Stable & 20 & 1 & 12 & $0.1 \pm 0.1$ & $1.5 \pm 0.4$ \\
Dynamic & 25 & 2 & 17 & $0.1 \pm 0.1$ & $2.6 \pm 0.9$ \\
Horse breed & & & & \\
Warmblood 139 & 54 & 78 & $1.2 \pm 0.2^{\mathrm{a}}$ & $1.6 \pm 0.2^{\mathrm{a}}$ \\
Icelandic & 88 & 9 & 24 & $0.3 \pm 0.1^{\mathrm{b}}$ & $0.7 \pm 0.2^{\mathrm{b}}$ \\
Other & 21 & 2 & 15 & $0.2 \pm 0.1^{\mathrm{ab}}$ & $1.4 \pm 0.3^{\mathrm{a}}$ \\
\hline
\end{tabular}

$\overline{\mathrm{a}-\mathrm{b}}$ Within columns, results without a common superscript differ significantly $(\mathrm{P}<0.05)$.

Most injuries following mixing were recorded on the horses' head, chest, rump and hindlegs (Fig. 1). On day 1 , Warmbloods had significantly more injuries located on the head ( $\mathrm{W}=8646, \mathrm{P}<0.001)$ and hindlegs $(\mathrm{W}=9217, \mathrm{P}=0.022)$ than Icelandic horses and also 4 weeks after grouping (head: $\mathrm{W}=9027, \mathrm{P}=0.005$; hindlegs: $\mathrm{W}=9066, \mathrm{P}<0.01)$. Overall, warmbloods also tended to have more injuries on the chest compared to other breeds ( $\mathrm{W}=37228, \mathrm{P}=0.08)$. Lameness was recorded directly after grouping in four horses (sncore 1) and 4 weeks later in one horse (score 2).

\subsection{Reactivity}

There were no significant differences in reactions toward the novel object between horses kept in similar and mixed age groups or between same and mixed sex groups $(P>0.05$, Table 4$)$. Only a few horses reacted when the object was placed in the paddock, but most horses showed a flight response when the object suddenly moved. The majority of horses investigated the object after it had moved, although only a few had resumed feeding within the $2 \mathrm{~min}$ of observation afterwards (Table 4).

Table 4. Median proportion (quartiles Q1, Q3) of horses in a group reacting with a flight response before the novel object (plastic bottles filled with stones bound to a rope) was suddenly moved, during the movement and the proportion of horses investigating the object and resuming feeding within 2 min afterwards. 


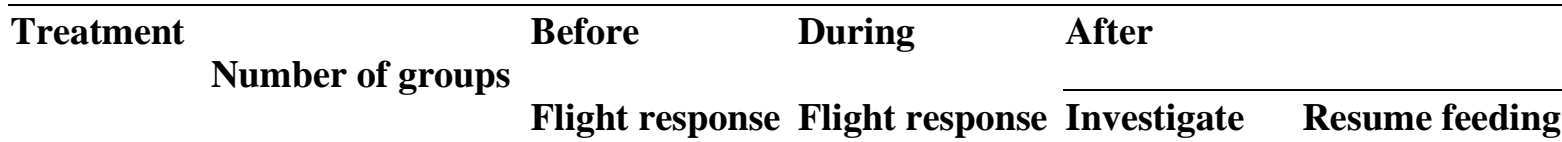

\begin{tabular}{lccccc}
\hline Age & & & & & \\
Similar & 12 & $0(0,0)$ & $1.0(0.8,1.0)$ & $1.0(0.6,1.0)$ & $1.0(0.5,1.0)$ \\
Mixed & 12 & $0(0,0)$ & $0.8(0.4,1.0)$ & $0.8(0.1,1.0)$ & $0.9(0.6,1.0)$
\end{tabular}

Sex

$\begin{array}{lcllll}\text { Female } & 8 & 0(0,0) & 1.0(0.5,1.0) & 0.6(0.3,0.7) & 0.4(0.0,0.5) \\ \text { Male } & 8 & 0(0,0) & 0.7(0.1,1.0) & 0.5(0.3,0.7) & 0.5(0.0,0.7) \\ \text { Mixed } & 6 & 0(0,0) & 0.7(0.3,1.0) & 0.6(0.3,0.8) & 0.3(0.2,0.4)\end{array}$

Horse breed

\begin{tabular}{|c|c|c|c|c|c|}
\hline Warmblood & & $0(0,0)$ & $1.0(0.8,1.0)^{\mathrm{a}}$ & $0.7(0.2,1.0)^{\mathrm{ab}}$ & $1.0(0.7,1.0)^{\mathrm{a}}$ \\
\hline Icelandic & 26 & $0(0,0)$ & $0.7(0.3,0.8)^{b}$ & $0.8(0.5,1.0)^{\mathrm{a}}$ & $0.6(0.3,0.8)^{\mathrm{ab}}$ \\
\hline her & 11 & $0(0,0)$ & $1.0(1.0,1.0)^{\mathrm{a}}$ & $0.3(0.2,0.7)^{\mathrm{b}}$ & $0.3(0.0,0.7)^{\mathrm{b}}$ \\
\hline
\end{tabular}

$\overline{\mathrm{a}-\mathrm{C} W i t h i n ~ c o l u m n s, ~ r e s u l t s ~ w i t h o u t ~ a ~ c o m m o n ~ s u p e r s c r i p t ~ d i f f e r ~ s i g n i f i c a n t l y ~}(\mathrm{P}<0.05)$.

Fewer Icelandic horses reacted when the object was moved compared to warmblood horses ( $\mathrm{W}=397$, $\mathrm{P}=0.007)$ and to the groups of horses of other breeds $(\mathrm{W}=389, \mathrm{P}<0.001$, Table 4). Furthermore, the median proportion of Icelandic horses investigating the object was higher than in groups of other breeds ( $\mathrm{W}=557, \mathrm{P}=0.04)$. Fewer horses of other breeds resumed feeding afterwards compared to the warmblood riding horse groups $(\mathrm{W}=79, \mathrm{P}=0.006)$.

\subsection{Ease of handling}

Horses of the mixed age groups were easier to halter than the young horses in the similar age groups $(\mathrm{W}=4, \mathrm{P}=0.03$ ) although the majority of horses could be haltered at the first attempt and easily led through the gate (Table 5). No differences in behaviour of the target horses were detected between groups of same or mixed sex $(\mathrm{P}>0.05)$. However, the loose horses in mixed sex groups tended to be less likely to approach the target horse and handler compared to the loose horses in all male groups $(\mathrm{W}=5, \mathrm{P}=0.06)$. Horses from all female groups tended to be more likely $(\mathrm{W}=6, \mathrm{P}=0.07)$ to follow the target horse in a friendly way while it was being separated from the group than were horses from mixed sex groups. Only two horses, one belonging to a female group and one to a male group approached the target horse and handler in a threatening manner.

Table 5. Median proportion (quartiles Q1, Q3) of the horses kept in same or mixed sex groups and same or mixed age groups that could be haltered and removed from the group, and the behaviour of other horses in the group toward the target horse and the handler. The lower the score the easier it was to separate the horse from the group. See Table 2 for full descriptions of the behavioural scores. 


\begin{tabular}{|c|c|c|c|c|c|c|c|}
\hline \multirow{2}{*}{$\begin{array}{l}\text { Treatments } \\
\text { (groups) }\end{array}$} & \multicolumn{3}{|c|}{ Target horse haltered } & \multicolumn{2}{|c|}{ Target horse led* } & \multicolumn{2}{|c|}{ Other horses** } \\
\hline & Score 1 & Score 2 & Score 3 & Score 1 & Score 2 & Score 1 & Score 2 \\
\hline \multicolumn{8}{|l|}{ Sex } \\
\hline $\begin{array}{l}\text { Mixed } \\
(\mathrm{n}=6)\end{array}$ & $\begin{array}{l}0.8(0.6 \\
1.0)\end{array}$ & $\begin{array}{l}0.0(0.0, \\
0.3)\end{array}$ & $\begin{array}{l}0.0(0.0 \\
0.4)\end{array}$ & $\begin{array}{l}0.8(0.6, \\
1.0)\end{array}$ & $\begin{array}{l}0.0(0.0 \\
0.3)\end{array}$ & $\begin{array}{l}0.8 \text { (0.6, } \\
0.8)^{(a)}\end{array}$ & $\begin{array}{l}0.3 \text { (0.2, } \\
0.4)^{(a)}\end{array}$ \\
\hline $\begin{array}{l}\text { Female } \\
(\mathrm{n}=8)\end{array}$ & $\begin{array}{l}0.8(0.6 \\
1.0)\end{array}$ & $\begin{array}{l}0.0(0.0 \\
0.3)\end{array}$ & $\begin{array}{l}0.0(0.0 \\
0.4)\end{array}$ & $\begin{array}{l}0.8(0.5, \\
1.0)\end{array}$ & $\begin{array}{l}0.0(0.0 \\
0.3)\end{array}$ & $\begin{array}{l}0.0(0.0 \\
0.3)^{(b)}\end{array}$ & $\begin{array}{l}0.9 \text { (0.7, } \\
1.0)^{(b)}\end{array}$ \\
\hline $\begin{array}{l}\text { Male } \\
(\mathrm{n}=8)\end{array}$ & $\begin{array}{l}0.9(0.4 \\
1.0)\end{array}$ & $\begin{array}{l}0.0(0.0 \\
0.3)\end{array}$ & $\begin{array}{l}0.0(0.0 \\
0.5)\end{array}$ & $\begin{array}{l}1.0(0.3, \\
1.0)\end{array}$ & $\begin{array}{l}0.0(0.0 \\
0.3)\end{array}$ & $\begin{array}{l}0.4(0.0 \\
0.7)^{(b)}\end{array}$ & $\begin{array}{l}0.6(0.3, \\
1.0)^{(\mathrm{b})}\end{array}$ \\
\hline \multicolumn{8}{|l|}{ Age } \\
\hline $\begin{array}{l}\text { Mixed } \\
(\mathrm{n}=10)\end{array}$ & $\begin{array}{l}0.6(0.4 \\
0.8)^{\mathrm{b}}\end{array}$ & $\begin{array}{l}0.0(0.0 \\
0.2)\end{array}$ & $\begin{array}{l}0.3(0.0 \\
0.6)\end{array}$ & $\begin{array}{l}0.4(0.2, \\
0.5)\end{array}$ & $\begin{array}{l}0.1(0.0 \\
0.6)\end{array}$ & $\begin{array}{l}0.0(0.0 \\
0.6)\end{array}$ & $\begin{array}{l}0.2(0.4 \text {, } \\
0.4)\end{array}$ \\
\hline $\begin{array}{r}\text { Similar } \\
(\mathrm{n}=10)\end{array}$ & $\begin{array}{l}0.3(0.0 \\
0.8)^{\mathrm{a}}\end{array}$ & $\begin{array}{l}0.0(0.0 \text {, } \\
0.4)\end{array}$ & $\begin{array}{l}0.3(0.0 \\
1.0)\end{array}$ & $\begin{array}{l}0.0(0.0, \\
0.3)\end{array}$ & $\begin{array}{l}0.3(0.0, \\
1.0)\end{array}$ & $\begin{array}{l}0.0(0.0, \\
0.4)\end{array}$ & $\begin{array}{l}0.1(0.4 \text {, } \\
0.6)\end{array}$ \\
\hline
\end{tabular}

\footnotetext{
*Score 3, results not presented since only 3 target horses out of a total of 145 horses that could be haltered were not successfully led through the gate

*Score 3, results not presented since on only 2 occasions out of a total 195 did other horses in the group approach the target horse and person aggressively.

a,bBetween columns, results without a common superscript differ significantly $(\mathrm{P}<0.05)$. (a),(b) tendency $\mathrm{P}<0.1$.
}

\section{Discussion}

The objective of our study was to investigate the effect of group composition on the occurrence of injury among horses, the ease of removing horses from groups and horses' reactivity to a fearful stimulus. The only effects of group social composition were related to the ease of separating a horse from its group, where the age composition of the group affected the ease of catching the target horse, and the sex composition tended to affect the level of interference from other flock members when the target horse was being led away. Irrespective of the social structure of the group, by far the majority of horses were easily haltered and separated from the group. Breed differences accounted for most variation in the number and location of new injuries and for the variation in reactivity. Icelandic horses had fewer injuries and fewer reacted to the movement of the novel object. Most injuries to horses were minor, involving only hair loss or lesions with moderately sized bruises or scrapes of the skin, not requiring any medical attention. Thus, the data collected gives little, if any, support for the belief that keeping horses in groups is associated with a risk of severe injuries in horses leading to long lasting loss of function. Despite the formation of 61 new groups, only two severe injuries to horses (defined as "wounds through the skin involving injury to deeper tissues, e.g. muscle, tendon or a wound through the skin without visible damage to underlying tissue but of a size that normally should be sutured by a vet”, Mejdell et al., 2010) were observed. We proposed that the optimal group has a stable membership of horses of mixed age and sex, but our results indicate that horses can be 
managed successfully (at least according to the variables recorded in this study), irrespective of the social composition of the group in which they are kept. In the following sections we discuss these results in more detail.

The incidence of severe injuries was very low and corresponds well with results from other research indicating that these injuries are rare in established groups of horses (Grogan and McDonnell, 2005; Lehmann et al., 2006; Jørgensen et al., 2009). Horses usually display threatening behaviour first in a conflict situation in order to avoid direct, violent contacts potentially leading to injury (Waring, 2003) and even stallions rarely hurt each other during inter-male combat (McDonnell and Haviland, 1995; Christensen et al., 2002). Thus, overt aggression is more likely to be a consequence of inappropriate management, which could include competition over limited resources such as feed or lack of space (Fureix et al., 2012), or lack of previous social experience (Christensen et al., 2002). The horses involved in this study had been kept in groups earlier and so had previous social experience with other horses, and all enclosures were relatively large (>0.5 ha).

Previous research has shown that when horses were introduced to each other in a standardized way, they behaved aggressively, but kicks or strikes did not result in actual body contact (Hartmann et al., 2009, 2011; Jørgensen et al., 2009). Our results suggest that immediately after establishing groups of horses new injuries do occur, and that new injuries continue to occur at least up to four weeks after mixing. It is also noteworthy that horses coming into the groups already had a large number of minor injuries, i.e. over half of the injuries recorded in this study were already present. Thus, it is not clear to what extent the injuries recorded in this study were caused by the regrouping or a consequence of living in a group. Injuries can be caused by aggressive encounters as the groups' social structure develops. Injuries can also be caused by rough social play or other behaviour (e.g. scratching) which increased the risk of being injured by features in the environment.

Group composition in terms of sex or age did not have an effect on the level of injuries. Fureix et al. (2012) propose that individual social characteristics of each group member may be more important than group composition per se, and it is known that aggressive interactions vary even in the same horse according to the behaviour of the other horse (Hartmann et al., 2009). Nevertheless, there is some evidence that the presence of a dominant older horse reduces aggression, and several authors advocate keeping young horses together with adult horses instead of having all youngsters in one group (Bourjade et al., 2008, 2009; Fureix et al., 2012). We found an effect of the breed of the horses in the group on number of injuries. Icelandic horses had fewer new injuries following regrouping than warmblood horses after regrouping. There is little evidence in the scientific literature that aggressiveness is related to breed (Fureix et al., 2012) but it is speculated that certain breeds may be more prone to get injured than others. Grogan and McDonnell (2005), for example, propose that Shetland ponies, because of their small size, may give less powerful kicks and buffer kicks or bites better due to their thicker coat and often higher body condition score. Icelandic horses are also smaller than warmbloods and generally have a thicker coat. Furthermore, the Icelandic horse is often referred to as being calm, with a low tendency to kick. The difference in the location of injuries on the day after mixing compared to when the horses had been in the group for four weeks may reflect differences in the types of interaction, including different orientations of the horses during the social interactions, as the social structure developed. For example, the higher initial level of injuries on the head may reflect more sniffing and investigation when the group is first formed (Hartmann et al., 2011). Differences in the number of injuries or their location could also be related to breed typical variations in temperament (Hausberger et al., 2004; Lloyd et al., 2008). Warmbloods, for example, have been selected for enhanced responsiveness and so score high in reactivity tests (von Borstel et al., 2010). 
Breed differences were likewise reflected in the lower proportion of Icelandic horses reacting when the novel object was suddenly moved compared to the warmblood and the other groups of horses. Breed differences in reaction to novelty were also observed by Lesimple et al. (2011) and discussed by Rørvang et al. (2015) but neither sex nor age had a significant effect on the horses' behaviour (Lesimple et al., 2011).

The presence of a calm companion together with a naïve horse can reduce fear reactions (Christensen et al., 2008). Thus, we predicted that the horses kept in similar age groups would react more to the novel object than horses in groups including older horses, which are sometimes less reactive than young horses. However, this was not the case. An effect of age was only found on the ease of haltering the horses. This is probably because there were more young horses in the similiar age groups and these horses may have had less experience of being handled. Of more relevance is the fact that there was a tendency in our study for less interference from other horses in the group when separating horses from a mixed sex group than there was when separating horses from a single sex group. This may reflect genuine differences in group cohesion (Hausberger et al., 2008). It supports the descriptive results of Jørgensen et al. (2011), but any possible differences in group cohesion depending on the sex composition of the group requires further scientific study.

\section{Conclusion}

Breed was the main factor accounting for differences in injuries and reactivity. This almost certainly reflected variations in temperament, i.e. Icelandic horses being usually calmer than more reactive warmbloods. Effects of the age and sex composition of the group were minor. The ease of separating a horse from its group is largely related to its experience with being led and separated from peers. However, keeping horses in mixed compared to same sex groups tended to decrease the likelihood of group members following the horse being removed. Overall, injuries recorded were only superficial, giving little support for the belief that keeping horses in groups increases the risk of severe injuries, at least when the horses are familiar with group housing.

\section{Acknowledgements}

The authors gratefully acknowledge the Nordic Joint Committee for Agricultural and Food Research (NKJ). The work was part of a Nordic collaborative project: Group housing of horses under Nordic conditions: Strategies to improve horse welfare and human safety. The final stages of this work were supported by the Centre of Excellence in Animal Welfare Science, a Swedish collaborative research platform supported by the Swedish Research Council Formas. The work was carried out in accordance with the ethical guidelines in each country and with the consent of the owners of the horses. 


\section{References}

American Association of Equine Practitioners (AAEP) Lameness exams: Evaluating the lame horse (2015) (Last accessed 29.11.15. http://www.aaep.org/info/horse-health?publication=836)

M. Bourjade, M. Moulinot, M.A. Richard-Yris, M. Hausberger. Could adults be used to improve social skills of young horses, Equus caballus? Dev. Psychobiol., 50 (2008), pp. 408-417

M. Bourjade, A.D. des Roches, M. Hausberger. Adult-young ratio, a major factor regulating social behaviour of young: a horse study. PLoS One, 4 (2009)

J.W. Christensen, J. Ladewig, E. Søndergaard, J. Malmkvist. Effects of individual versus group stabling on social behaviour in domestic stallions. Appl. Anim. Behav. Sci., 75 (2002), pp. 233-248

J.W. Christensen, J. Malmkvist, B.L. Nielsen, L.J. Keeling. Effects of a calm companion on fear reactions in naive test horses. Equine Vet. J., 40 (2008), pp. 46-50

J.W. Christensen, E. Sondergaard, K. Thodberg, U. Halekoh. Effects of repeated regrouping on horse behaviour and injuries. Appl. Anim. Behav. Sci., 133 (2011), pp. 199-206

A. Fürst, J. Knubben, A. Kurtz, J. Auer, M. Stauffacher. Group housing of horses: veterinary considerations with a focus on the prevention of bite and kick injuries. Pferdeheilkunde, 22 (2006), pp. 254-258

B. Flauger, K. Krueger. Aggression level and enclosure size in horses (Equus caballus).

Pferdeheilkunde, 29 (2013), pp. 495-504

C. Fureix, M. Bourjade, S. Henry, C. Sankey, M. Hausberger. Exploring aggression regulation in managed groups of horses Equus caballus. Appl. Anim. Behav. Sci., 138 (2012), pp. 216-228

E. Grogan, S. McDonnell. Injuries and blemishes in a semi-feral herd of ponies. J. Equine Vet. Sci., 25 (2005), pp. 26-30

E. Hartmann, J.W. Christensen, L.J. Keeling. Social interactions of unfamiliar horses during paired encounters: effect of pre-exposure on aggression level and so risk of injury. Appl. Anim. Behav. Sci., 121 (2009), pp. 214-221

E. Hartmann, L.J. Keeling, M. Rundgren. Comparison of 3 methods for mixing unfamiliar horses (Equus caballus). J. Vet. Behav.: Clin. Appl. Res., 6 (2011), pp. 39-49

E. Hartmann, E. Søndergaard, L.J. Keeling. Keeping horses in groups: a review. Appl. Anim. Behav. Sci., 136 (2012), pp. 77-87

E. Hartmann, E. Søndergaard, L.J. Keeling. Identifying potential risk situations for humans when removing horses from groups. Appl. Anim. Behav. Sci., 136 (2012), pp. 37-43

E. Hartmann, K.E. Bøe, J.W. Christensen, S. Hyyppä, H. Jansson, G.H.M. Jørgensen, J. Ladewig, C.M. Mejdell, Y. Norling, M. Rundgren, S. Särkijärvi, E. Søndergaard, L.J. Keeling. A Nordic survey of management practices and owners' attitudes towards keeping horses in groups. J. Anim. Sci., 93 (2015), pp. 4564-4574 
M. Hausberger, C. Bruderer, N.L. Scolan, J.S. Pierre. Interplay between environmental and genetic factors in temperament/personality traits in horses (Equus caballus). J. Comp. Psychol., 118 (2004), pp. 434-446

M. Hausberger, H. Roche, S. Henry, E.K. Visser. A review of the human-horse relationship. Appl. Anim. Behav. Sci., 109 (2008), pp. 1-24

G. Jørgensen, L. Borsheim, C. Mejdell, E. Sondergaard, K. Bøe. Grouping horses according to gender - effects on aggression, spacing and injuries. Appl. Anim. Behav. Sci., 120 (2009), pp. 94-99

G.H.M. Jørgensen, K.E. Fremstad, C.M. Mejdell, K.E. Bøe. Separating a horse from the social group for riding or training purposes: a descriptive study of human-horse interactions. Anim. Welf., 20 (2011)

J.M. Knubben, A. Fürst, L. Gygax, M. Stauffacher. Bite and kick injuries in horses: prevalence: risk factors and prevention. Equine Vet. J., 40 (2008), pp. 219-223

J.M. Knubben, L. Gygax, M. Stauffacher. Horses in Switzerland: results of a representative survey of population, housing and use in 2004. Schweiz. Arch. Tierh., 150 (2008), pp. 387-397

K. Lehmann, E. Kallweit, F. Ellendorff. Social hierarchy in exercised and untrained group-housed horses - a brief report. Appl. Anim. Behav. Sci., 96 (2006), pp. 343-347

C. Lesimple, C. Fureix, N. LeScolan, M.-A. Richard-Yris, M. Hausberger. Housing conditions and breed are associated with emotionality and cognitive abilities in riding school horses. Appl. Anim. Behav. Sci., 129 (2011), pp. 92-99

A.S. Lloyd, J.E. Martin, H.L.I. Bornett-Gauci, R.G. Wilkinson. Horse personality: variation between breeds. Appl. Anim. Behav. Sci., 112 (2008), pp. 369-383

S.M. McDonnell, J.C.S. Haviland. Agonistic ethogram of the equid bachelor band. Appl. Anim. Behav. Sci., 43 (1995), pp. 147-188

C. Mejdell, G. Jorgensen, T. Rehn, K. Fremstad, L. Keeling, K. Bøe. Reliability of an injury scoring system for horses. Acta Vet. Scand., 52 (2010), p. 68

M.V. Rørvang, L. Peerstrup Ahrendt, J. Winther Christensen. A trained demonstrator has a calming effect on naïve horses when crossing a novel surface. Appl. Anim. Behav. Sci., 171 (2015), pp. 117120

U.U.K. von Borstel, I.J.H. Duncan, M.C. Lundin, L.J. Keeling. Fear reactions in trained and untrained horses from dressage and show-jumping breeding lines. Appl. Anim. Behav. Sci., 125 (2010), pp. $124-131$

G.H. Waring. Horse Behavior. William Andrew Publishing, New York (2003)

C.E. Wylie, J.L. Ireland, S.N. Collins, K.L.P. Verheyen, J.R. Newton. Demographics and management practices of horses and ponies in Great Britain: a cross-sectional study. Res. Vet. Sci., 95 (2013), pp. 410-417 